\title{
A hipertóniától a szívelégtelenségig
}

\author{
Magyar Klára, Deres László, Gál Roland, Riba Ádám, Habon Tamás, \\ Tóth Kálmán, Halmosi Róbert
}

\author{
Pécsi Tudományegyetem, Klinikai Központ, I. sz. Belgyógyászati Klinika, Pécs \\ Levelezési cím: Dr. Halmosi Róbert egyetemi docens, Pécsi Tudományegyetem, I. sz. Belgyógyászati Klinika \\ E-mail: halmosi.robert@pte.hu
}

\begin{abstract}
A hipertónia világszerte növekvő egészségügyi problémát jelent az idősödő társadalmakban. A magasvérnyomás-betegség a szívelégtelenség egyik legfontosabb rizikófaktora. A hipertenzív szívbetegségben a nyomásterhelésre kezdetben kompenzációs mechanizmusként kialakuló balkamra-hipertrófia fokozatosan - kezdetben megtartott (HFpEF), majd késöbb csökkent ejekciós frakciójú (HFrEF) - szívelégtelenséget eredményez. A folyamat hátterében a mechanikai stressz indukálta neurohumorális aktiváció és jelátviteli faktorok modulációja által kiváltott szívizomsejt-hipertrófia és intersticiális kötőszöveti felszaporodás játszik szerepet.

A sokféle hatékony vérnyomáscsökkentő gyógyszer ellenére a betegek egy részében nehézségbe ütközik a célvérnyomásérték elérése a vérnyomáscsökkentő gyógyszerek, vagy a vérnyomás csökkentése által előidézett mellékhatások, panaszok miatt. Ezért számos vizsgálat irányult a célszervkárosodások kialakulásának megakadályozására (pl. Rho/ ROCK jelátviteli út gátlása, szabadgyök-képződés szabályozása, mitokondriális biogenezis befolyásolása, rekombináns adenovírus hepatocita növekedési faktor gén expressziófokozása).

A hipertónia indukálta oxidatív stressz DNS-töréseken keresztül aktiválja a sejtmagban található poli(ADP-ribóz) polimeráz-1 (PARP) enzimet, amely a sejtek energiaraktárainak kimerüléséhez és a remodellingben szerepet játszó különböző jelátviteli utak aktiválódásához vezet. A PARP-enzim aktivációjának fontos szerepe van a hipertenzív szívbetegség, illetve végső soron a szívelégtelenség kialakulásában. Ezért a PARP-enzim gátlása is egy új terápiás alternatívát nyújthat a magas vérnyomás következményeinek mérséklésében. Összefoglaló közleményünk célja a hipertenzív szívbetegség kialakulásában szerepet játszó mechanizmusok, illetve azok terápiás befolyásolási lehetőségeinek bemutatása.
\end{abstract}

Kulcsszavak: hipertónia, hipertenzív szívbetegség, HfpEF, célszervkárosodás, PARP-gátlás

\section{From hypertension to heart failure}

Hypertension is an increasing health problem worldwide especially among the elderly. Its therapeutical importance is indicated by the caused organ damages like hypertensive heart disease (HHD) and heart failure with the subsequent higher morbidity and mortality in the population. In HHD ventricular hypertrophy develops as a compensatory mechanism for pressure overload but as the left ventricular compliance decreases, the process can transform into heart failure with firstly preserved and then into reduced ejection fraction (HFpEF, HFrEF). The main characteristics of underlying mechanisms involve cardiomyocyte growth, vessel changes, increased collagen production in all of which several mechanical stress induced neurohumoral agents, signal transduction pathways are involved.

Occasionally, patients are not able to tolerate antihypertensive medication because of side effects, drug intolerance or interactions thus it is more difficult to reach the target blood pressure values. Therefore there are several efforts to complete the existing therapeutical possibilities against the development of organ damages like inhibition of Rho/ROCK pathway, regulation of ROS formation, influence on mitochondrial biogenesis and enhancing recombinant adenovirus hepatocyte growth factor gene.

Hypertension induced oxidative stress causes DNA breaks producing the activation of nuclear poly(ADP-ribose) polymerase-1 (PARP) enzyme that leads to energy depletion and unfavorable modulation of different kinase cascades. PARP activation promotes the development of HHD, and its transition to heart failure. Therefore inhibition of PARP-enzyme offers another new therapeutical approach among hypertensive patients. The purpose of this review is to give a comprehensive summary about the most significant mechanisms in HHD and an insight into new potential therapies.

Keywords: hypertension, hypertensive heart disease, HfpEF, organ damage, PARP-inhibition 


\section{Bevezetés}

A hipertónia prevalenciája világszerte növekszik, amely egyre nagyobb mortalitási és morbiditási rizikóval társul társadalmi szinten. A hipertónia a populáció 30-40\%-át érinti és az életkor előrehaladtával fokozatosan emelkedik. Magasvérnyomás-betegségről a jelenlegi irányelvek szerint $140 \mathrm{Hgmm}$ feletti szisztolés és $90 \mathrm{Hgmm}$ feletti diasztolés vérnyomásérték esetén beszélünk és hipertónia kezelése esetén ezen vérnyomás elérése a célunk. Bizonyos betegcsoportok esetén kevésbé szigorú célértékek kerültek meghatározásra. Az idős betegek többet profitálnak abból, ha a szisztolés vérnyomásuk 140-150 Hgmm közötti értékre van beállítva. Diabéteszes betegekben azonban az átlagpopulációhoz képest alacsonyabb, $85 \mathrm{Hgmm}$ alatti diasztolés célvérnyomás elérése fontos. Míg korábban azt gondoltuk, hogy annál jobb a betegek életkilátása, minél alacsonyabb a vérnyomása, addig ma az evidenciák zöme a „J-görbe” hipotézist támasztják alá. Eszerint a szisztolés és diasztolés vérnyomásérték túlzott mértékủ csökkentése káros is lehet.

A hipertónia a szívelégtelenség mellett releváns rizikófaktora a kardiovaszkuláris betegségek, stroke, vesebetegségek és perifériás érbetegségek kialakulásának is (1). Epidemiológiai adatok szerint a tartósan magas vérnyomás következtében kialakuló egyik legjelentősebb célszervkárosodásnak a hipertenzív szívbetegség (HHD) tartható. A HHD fokozza a szívelégtelenség, iszkémiás szívbetegség és az aritmiák kialakulását. A Framingham-vizsgálatban is kimutatták, hogy 20 Hgmm-es szisztolés vérnyomás-emelkedés több mint $50 \%$-kal növeli a szívelégtelenség rizikóját (2).

A hipertónia természetesen nem az egyetlen faktor, amely hozzájárul a szívelégtelenség kialakulásához. Az egyén számára a korábban lezajlott szívinfarktus jelenti a legnagyobb kockázatot, azonban populációs szinten a magasvérnyomás-betegség a legfontosabb rizikófaktora a szívelégtelenségnek (3). Regiszterek adataiból tudjuk, hogy a szívelégtelen betegek közel felének megtartott ejekciós frakciója van (HFpEF), amely inkább az idősebbek, diabéteszesek, a nők és a hipertóniás betegek körében fordul elö. A HFpEF kialakulására és progressziójára nézve a hipertónia különösen fontos rizikófaktor (4).

Ezért van nagy jelentősége a megfelelő vérnyomáscsökkentő kezelésnek, illetve elsődlegesen magának a vérnyomáscsökkentésnek, amely megelőzheti ezen betegcsoportban a hipertónia következtében kialakuló major kardiovaszkuláris események (CV), a HHD és a szívelégtelenség előfordulását (5).

\section{A hipertenzív szívbetegség kialakulása}

A hipertenzív szívbetegség spektruma klinikai megjelenés szempontjából igen széles, amelybe az aszimp- tomatikus balkamra-hipertrófia és a szívelégtelenség különféle fajtái (HFpEF, HFmrEF - szívelégtelenség mérsékelten csökkent EF-fel és HFrEF) is beletartozik. A tartósan fennáló magas vérnyomás változásokat hoz létre az erek és a bal kamra struktúrájában, geometriájában, formájában, illetve funkciójában. Ezeket az elváltozásokat összefoglaló néven remodellingnek nevezzük. A szívizomzat tekintetében a remodelling következtében a bal kamra falának megvastagodását látjuk $(6,7)$.

A balkamra-hipertrófia egy adaptív, kompenzatorikus mechanizmus, amelynek hatására a nyomás- és volumentúlterhelés által fokozott falfeszülés csökken és a szív teljesítménye megtartott marad (Laplace törvénye). A bal kamrai tömeg növekedésének több fajtája ismert, lehet excentrikus vagy koncentrikus. Ezek között a relatív falvastagság (a bal kamrai falvastagságok összegének aránya a bal kamrai végdiasztolés átméröhöz) segítségével tehetünk különbséget. Hogy a hipertrófia melyik fajtája alakul ki, befolyásolja a terhelés fajája (nyomás-, vagy volumentúlterhelés), a neurohumorális aktiváció foka (pl. plazma reninszint), az extracelluláris mátrix változások, társbetegségek (koronáriabetegség, diabetes mellitus, obesitas), valamint demográfiai és genetikai tényezők (pl. ACE-gén polimorfizmus) $(7,8)$. A balkamra-hipertrófia kialakulása a legfontosabb predisponáló tényezője a manifeszt szívelégtelenség kialakulásának hipertóniás betegekben (7). Ma már jól ismert, hogy a szimptomatikus szívelégtelenség csökkent EF (HFrEF) mellett megtartott (HFpEF) és "mid-range” (HFmrEF) ejekciós frakció esetén is kialakulhat (9). A HHD kialakulásának klasszikus lefolyása a bal kamra ún.

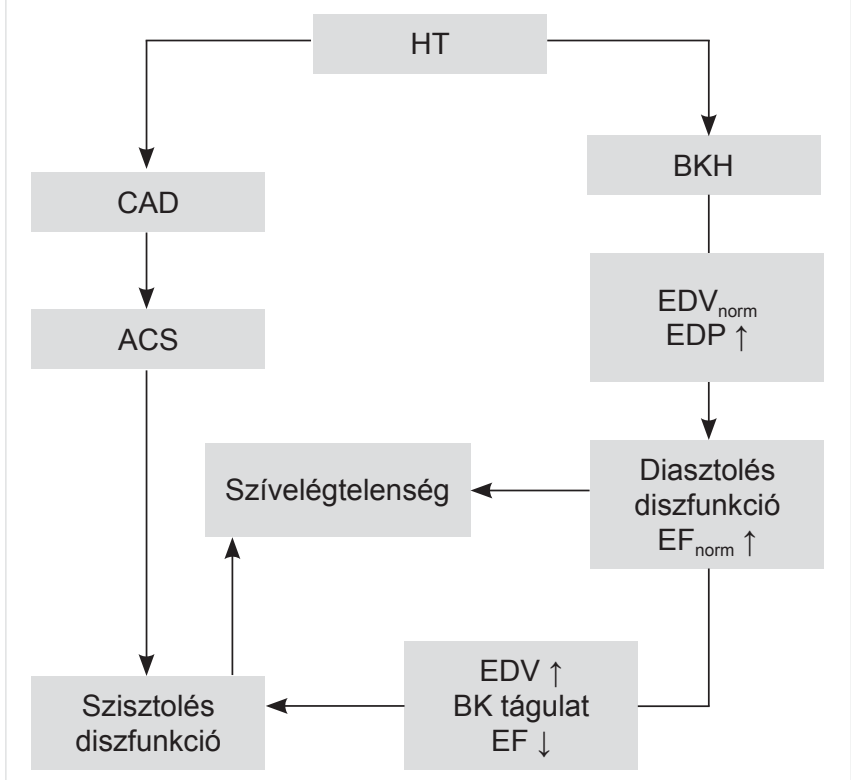

1. ÁBRA. A szívelégtelenség kialakulásának folyamata hipertóniában. HT: hipertónia; BKH: balkamra-hipertrófia; EDV: végdiasztolés volumen; EDP: végdiasztolés nyomás; EF: ejekciós frakció; CAD: koszorúér-betegség; ACS: akut koronária szindróma, SZE: szívelégtelenség, BK: bal kamra 
„kiégése”, amely során a hipertónia koncentrikus balkamra-hipertrófiához vezet, amelyet diasztolés, majd végül szisztolés balkamra-elégtelenség követ (10). A hipertóniás betegek egy másik csoportjában a koszorúér-betegség, a szívinfarktus a balkamra-hipertrófiától függetlenül, közvetlenül vezethet a HFrEF kialakulásához (8) (1. ábra).

\section{Hisztológiai eltérések}

A hipertónia által előidézett struktúrális szívizom-elváltozások a szív teljesítményének és a koronáriakeringés hatékonyságának romlásához vezetnek. A HHD patogenezise a szív minden komponensét érinti, beleértve koszorúereket, a szívizom-sejteket, a nem miocita sejteket, a fibroblasztokat, az endotheliális sejteket, az extracelluláris matrix fehériéit, és a fibrilláris típusú kollagént is (11). A HHD-ban létrejövő struktúrális átépülés megváltozott energia-metabolizmusú hipertrofizált miocitákkal, fokozott fibroblaszt-proliferációval és aktivációval, fibroblaszt-miofibroblaszt transzformációval, és nagymértékủ kollagénlerakódással jellemezhető, amely sokkal merevebb, kevésbé energiahatékony myocardium kialakulásához vezet $(12,13)$. A koronária rezisztenciaerek szintén érintettek, az intramiokardiális artériák és arteriolák falának megvastagodása mellett perivaszkuláris fibrózis is jelen van, melyek mindegyike csökkenti a perfúzió hatékonyságát (14).

\section{Neurohumorális mechanizmusok}

A szív átépülésének szabályozásában számos neurogén, humorális, autokrin és parakrin faktor vesz részt. A renin-angiotenzin-aldoszteron-rendszer aktivációja (RAAS) egyike a legfontosabb folyamatoknak, amely hozzájárul a hipertónia kialakuláshoz, beleértve a kiváltott vazokonstrikciót, reaktív oxigén szabad gyökök (ROS) képződését, az érfalban kialakuló gyulladásos választ, továbbá a vaszkuláris és kardiális átépülést (hipertrófia és fibrózis). Ezért a RAAS-rendszer igen jelentős szerepet játszik a hipertenzív célszervkárosodások kialakulásában $(15,16)$ is. Az angiotenzin konvertáló enzim (ACE) felelős az angiotenzin-II (Ang-II) képződésért, amely korrellál a balkamra-hipertrófia mértékével. Egyénileg változó a plazma ACE-koncentrációja az ACE-gén inszerciós/deléciós polimorfizmusa miatt, amely szintén szorosan összefügg a balkamra-hipertrófia kialakulásával (12). A mineralokortikoidoknak a volumen regulációban van fiziológiás szerepük, szimpatikus idegrendszeri aktivációt is okoznak, ami baroreceptor-diszfunkcióhoz, károsodott artériás compliance-hez, jelentős miokardiális és vaszkuláris fibrózishoz vezet (17). A szimpatikus hiperaktiváció direkt módon emeli a vérnyomást (a RAAS-rendszer aktivációja nélkül), kedvezőtlen metabolikus hatásai vannak (pl. inzulinrezisztenciát okoz), valamint elősegíti a balkamra-hipertrófia kialakulását.
Már jól ismert, hogy a kardiális remodelláció patogenezise inzulinrezisztenciával, fokozott inzulinszerü növekedési faktor-1, profibrotikus matricelluláris osteopontin, pajzsmirigyhormon és emelkedett agyi és pitvari nátriuretikus peptid aktivitással társul (12).

A ROS okozta károsodásoknak az endothel-diszfunkció, a gyulladásos válasz, a hipertrófia, apoptózis, sejtvándorlás, fibrózis és az angiogenezis során is igen jelentős szerepe van $(18,19)$. Továbbá károsítják az ioncsatornák müködését és csökkentik a nagy energiájú foszfátok mennyiségét. Mindezek következtében megváltozik a szívizomsejtek és a simaizomsejtek homeosztázisa, amely sejtproliferációt vált ki (20). A fokozott oxidatív stressz egyes láncú DNS-törésekhez vezet, amelyek hatására aktiválódik a nukleáris poli(ADP-ribóz) polimeráz-1 (PARP) enzim. A PARP-enzim elhasználja a sejt NAD+ és ATP raktárait és egy energiahiányos állapotot hoz létre, amely inadekvát glikolízishez vezet és csökkenti a mitokondriális légzési lánc aktivitását, elősegítve ezzel az apoptotikus és nekrotikus sejthalált (21-25). A PARP-enzim aktivációjának központi szerepe van számos kardiovaszkuláris betegség patofiziológiájában, ezek közé tartozik a HHD, majd a szívelégtelenség kialakulása, mivel képes a különböző kináz kaszkádok modulációján keresztül a kollagén termelődést mérsékelni $(21,22)$. A szív sejtszintủ adaptációs válaszai típusosan stresszfüggő jelátviteli utakon keresztül jönnek létre, amelyek centrális jelátalakító szerepet töltenek be kardiális hipertrófia és/ vagy a kamrák dilatációja esetén.

Az extracelluláris szignál-regulált protein-kináz (ERK), p38 mitogén aktiválta protein-kináz (p38-MAPK), c-Jun NH2 terminális kinázok (JNK), számos protein-kináz C-izoforma (PKC delta és epszilon) és az Akt-1/gliko-

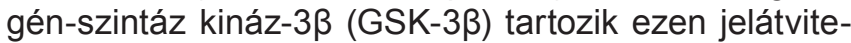
li útvonalak közé. Ezek a kaszkádok részt vesznek a miociták túlélésében (Akt-1/GSK-3ß, ERK, PKCepsziIon, JAK), vagy pedig programozott sejthalálában (p38 MAPK, PKC delta, JNK) (20-22) (2. ábra). Egyre több irodalmi adat bizonyítja, hogy a RhoA/ROCK jelátviteli útvonal szintén érintett a hipertónia és a balkamra-hipertrófia kialakulásában. Működése szorosan öszszefügg az Ang-II-vel, mely serkenti a ROCK jelátviteli útvonal aktivitását, hozzájárulva a hipertónia fennmaradásához, a koszorúerekben megnövekedett media vastagságához és a perivaszkuláris fibrózis fokozódásához (26). Ez a mechanizmus szintén befolyásolja a falfeszülés-indukálta ERK-aktivációt és a vaszkuláris simaizomsejtek növekedését (27).

\section{Terápiás lehetőségek hipertóniában}

Az antihipertenzív kezelés legfontosabb célja az életveszélyes célszervkárosodások, mint a stroke, miokardiális infarktus, HHD, és a szívelégtelenség megelőzése (1). A szívelégtelenség kezelése rendkívül fontos és 

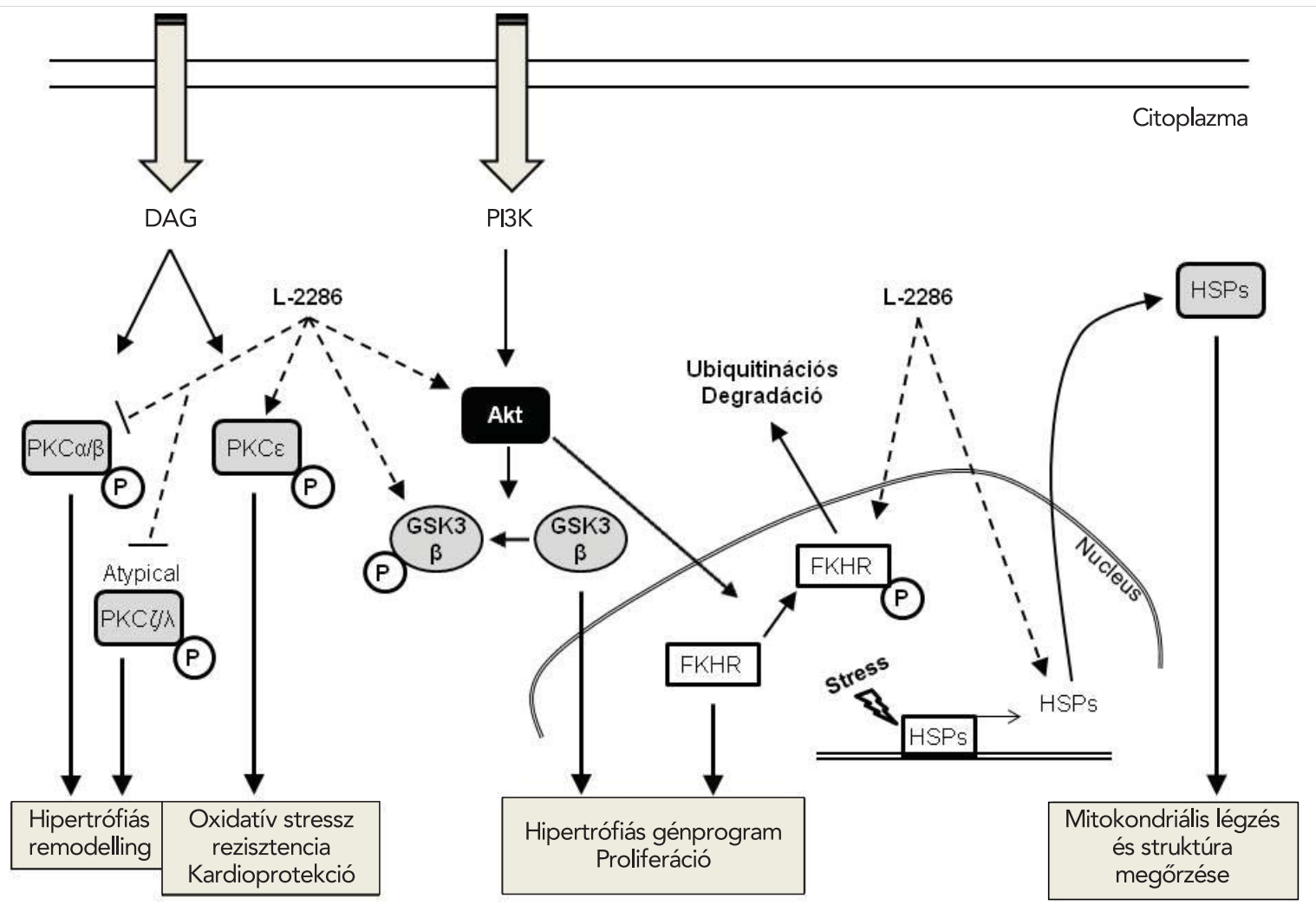

2. ÁBRA. (ADP-ribóz) polimeráz-1 gátlás hatásának összefoglalása a protein-kináz $C$ and Akt-1/GSK-3ß jelátviteli útvonalakra (Deres L. és a szerzők engedélyével). DAG: Diacil-glicerol; FKHR: Forkhead transzkripciós faktor; GSK-3ß: Glikogén-szintáz kináz-3ß; HSP: Hősokk-fehérje; PARP: Poli(ADP-ribóz) polimeráz; PI3K: Foszfatidil-inozitol 3-kináz; PKC: Protein-kináz C.

sikeres terápiás lehetőség a mortalitás csökkentésére, azonban a szívelégtelenség megelőzése mind a beteg számára, mind pedig financiális szempontból előnyösebb. Jól ismert, hogy a hatékony antihipertenzív kezelés több mint $50 \%$-kal csökkenti a szívelégtelenség előfordulását (28). A jelenlegi irányelvek alapján az antihipertenzív terápia sarokköveit a diuretikumok, a béta-blokkolók, az angiotenzin konvertáz enzim gátlók (ACE-I), az angiotenzinreceptor-blokkolók (ARB) és a kalciumantagonisták (CA) képezik (29).

A szimpatikus aktivitás gátlása nélkülözhetetlen a hipertónia kezelésében. A béta-blokkolók vérnyomáscsökkentő hatás mellett a szimpatikus túlmüködés mérséklésével védenek a hirtelen szívhalál ellen. Továbbá lassítják a bal kamrai remodellációt és csökkentik a szívelégtelenség előfordulását.

A diuretikumok közül a thiazidok jelentik az első vonalbeli választást a hatékonyságuk miatt. Mérséklik a balkamra-hipertrófia mértékét és hatékonyan csökkentik a kardiovaszkuláris morbiditást és mortalitást.

Az ARB-k és különösen az ACE-gátlók szintén szignifikáns mértékben csökkentik a hipertóniás betegek mortalitását. Az ACE-gátlók megelőzik egyaránt a szívelégtelenséget és csökkentik a bal kamrai és vaszkuláris remodellinget. Ezek a folyamatok az intersticiális kollagéntermelődésben szerepet játszó enzimatikus folyamatok downregulációja következtében jönnek létre.
A kalciumcsatorna-blokkolók effektíven csökkentik a vérnyomást, artériadilatációt okozva a $\mathrm{Ca}^{(2+)}$-beáramlás csökkentése révén a simaizomsejtekben az érfalban. $A$ legtöbb antihipertenzív gyógyszerrel kombinációs terápiában is alkalmazhatóak. Ráadásul több vizsgálat szerint lassítják az ateroszklerózis folyamatát is (30).

Az ESC- és ESH-irányelvek szerint a fent említett gyógyszerek mellett egyéb szerek is használhatók az antihipertenzív kezelésben, mivel a legfőbb terápiás haszon a vérnyomáscsökkentő hatáson alapszik és független a gyógyszer típusától (28).

\section{Ưj terápiás lehetősségek hipertóniában}

A klinikai gyakorlatban monoterápiában, vagy akár kombinációban alkalmazott hatékony antihipertenzív gyógyszeres kezelés ellenére a betegek jelentős részénél a célvérnyomás-értékek sajnos nem elérhetőek. Az Egyesült Államokban a kb. 70 millió hipertóniás beteg közül kb. 40 millió betegnek a vérnyomása nincs a megfelelő tartományban. Ennek hátterében lévő legjelentősebb tényezők a kialakuló gyógyszermellékhatások, -intolerancia és az ennek következtében a betegek csökkent gyógyszerszedési adherenciája állnak (29). Az utóbbi években egyre több kutatás középpontjában olyan kezelési lehetőségek szerepelnek, amelyek mér- 
séklik a célszervkárosodások kialakulását a vérnyomásérték befolyásolása nélkül.

Egyre több adat áll rendelkezésünkre, hogy a Rho kináz (ROCK) enzimcsalád fontos szerepet játszik a kardiovaszkuláris betegségek, ezen belül a kardiális fibrózis, hipertrófia és a szívelégtelenség kialakulásában. A jelenleg is zajló vizsgálatokban a ROCK-gátlók pl. fasudil adása kedvezőnek bizonyult a kardiális remodelling szempontjából. Klinikai vizsgálatokban a leukociták ROCK aktivitását emelkedettnek észlelték balkamra-hipertrófiás betegekben, azokhoz képest, akiknél még nem fejlődött ki a balkamra-hipertrófia (31). Állatkísérletekben a ROCK gátlása mérsékelte a cardiomyocyta-hipertrófiát gátolva az angiotenzin-II, az endotelin-1 jelátviteli útvonalakat a PI3K/ Akt és ERK/MAPK akivációján, valamint a Bcl-2 proapoptotikus család és a Bax gátlásán keresztül (32). Egy kisebb klinikai vizsgálatban hipertenzív betegek fasudil terápiában részesültek a perifériás vaszkuláris rezisztencia csökkenését észlelték (33). A statinok ún. pleotróp hatásainak egy része is a ROCK-gátláson keresztül érvényesül. Ezek befolyásolása által részt vesznek a sejtek növekedésének regulációjában/apoptotikus válaszaiban és bizonyos gének expressziójának szabályozásában (Ras, Rac, Rab and Rho) $(34,35)$. Ezek az eredmények új terápiás lehetőségeket nyitnak meg szelektív ROCK1- vagy ROCK2-gátlók kifejlesztésének irányába, amelyeknek szélesebb terápiás hatákonysága lehet kevesebb toxikus mellékhatással (34).

A mitokondriális diszfunkció szintén jelentős tényezőnek tűnik a HHD kialakulásának szempontjából (29, 36, 37). Ezért újabb terápiás lehetőségként felmerül a mitokondriális biogenezis stimulálása az AMPK vagy az eNOS/nitrogén-monoxid/ciklikus guanozin-monofoszfát útvonalon (37-43). A kedvező kardiovaszkuláris prevenciós hatásáról már ismert rezveratrol is potens stimulátora a mitokondriális biogenezisnek (44-49). Egy másik lehetőség a mitokondriális védelemre az oxidatíve stressz ellen az ACE-gátlók ATII-receptor-blokkolók alkalmazása, amelyek antihipertenzív tulajdonságuk mellett antioxidáns hatással is bírnak. Jelenleg még pontosan nem tisztázott, hogy direkt, vagy indirekt módon gátolják a mitokondriális szabadgyök-képződést $(50,51)$. A mitokondriális vashomeosztázis szabályozásának és a mitokondriális vastartalom csökkentésének szintén kardioprotektív szerepe van a szabadgyök-képződés és az oxidatív stressz mérséklésén keresztül (36). Egyre növekvő számú bizonyíték áll rendelkezésünkre, hogy a fent említett rezveratrol mérsékli a balkamra-diszfunkció kialakulását (52). Spontán hipertenzív patkánymodellben (SHR), illetve aortakonstrikciós (TAC) szívelégtelenség modellekben is kimutatták ezen kedvező hatását. Habár a rezveratrol nem befolyásolja a szisztolés és diasztolés vérnyomásértékeket, TAC patkánymodellben jelentős mértékben fokozta a glutation, szuperoxid-dizmutáz2 szintjét, csökkentette a 4-hidroxi2-nonenal mennyiségét - amely a lipid-peroxidáció markere -, a bal kamrában pedig a makrofág és masz- tocita infiltrációt. A rezveratrol-hidralazin kombinációs terápia szignifikáns mértékben csökkentette a vérnyomást, javította a szisztolés és diasztolés balkamra-funkciót, a vaszkuláris geometriát és csökkentette a fibrózis mértékét. $A$ kis dózisú rezveratrol adása önmagában nem érte el ezeket a kedvező hatásokat, habár a fibrózis mértéke és néhány funkcionális eltérés esetén javulást tapasztaltak ebben az esetben is SHR-ben (53).

A késői nátrium csatornák fokozott müködése a szabad $\mathrm{Ca}^{(2+)}$-koncentráció megemelkedéséhez vezet, amelynek szerepe van a balkamra-hipertrófia kialakulásában. SHR-ben kimutatták, hogy az antianginás szerként ismert ranolazin lassítja a balkamra-hipertrófia mértékét, valamint a szívelégtelenségbe való progreszszió során létrejövő ultrastrukturális és a fiziológiai elváltozásokat. Továbbá hatékonynak bizonyult a diasztolés diszfunkció kialakulásának mérséklésében, mivel gátolta a késői nátriumcsatornákat és ezáltal csökkent $\mathrm{Ca}^{(2+)}$-koncentrációhoz vezetett (54). Hu és munkatársai vizsgálták a HGF csökkent expresszióját hipertrófiás és a fibrotikus SHR myocardiumban, ezért rekombináns adenovirus hepatocita növekedési faktor gént (Ad-HGF gén) fecskendeztek a bal kamra szabad falába. A miokadiális HGF-expresszió fokozódása SHRben szignifikáns mértékben csökkentette a miokardiális fibrózist, az I. típusú kollagén mennyiségét, a bal kamrai tömegindexet, és fokozta a dp/dt max értéket (55). $A z$ elmúlt évtizedben egyre inkább a figyelem középpontjába kerültek a PARP-gátlók. Habár nem rendelkeznek antihipertenzív hatással, munkacsoportunk igazolta, hogy egy isoquinolin derivátum PARP-gátló vegyület, az L-2286 kedvezően befolyásolja az oxidatív sejtkárosodást, az iszkémia-reperfúziós sérülést és a szívelégtelenség kialakulását posztinfarktusos, valamint hipertóniás állatmodellekben $(21,22,25,56,57)$. A PARP-gátló kezelés szignifikáns mértékben csökkentette a kollagénlerakódást a myocardiumban, valamint az echokardiográfiával mért balkamra-hipertrófia mértékét. Idős SHR-állatokban a PARP-gátló kezelés a már kifejlődött HHD szívelégtelenségbe való progreszszióját akadályozta meg. Fiatal SHR-állatokban pedig a HHD kifejlődését lassította (22). Egy további vizsgálatban SHR-állatokban a PARP-gátlók mérsékelték a nagyerek hipertenzív átépülését. Kísérletes adataink igazolják, hogy a PARP-gátló kezelésnek a hipertenzív célszervkárosodások kialakulásával szembeni védő hatásában az Akt-1/GSK-3 $\beta$ útvonal, a PKC izoformák, valamint az MKP-1 és MAP-kinázok befolyásolása fontos szerepet játszanak $(21,22,25,56,57)$. Az újszerü koncepció, hogy a célszervkárosodások mérsékelhetők vérnyomáscsökkentés nélkül is hipertóniás betegekben igen ígéretesnek látszik, mivel a célvérnyomás-érték ez esetek jelentős részében nem elérhetőek. Ezért az irányelvekből is jól ismert antihipertenzív kezelés kombinálása pl. egy PARP-gátló hatású vegyülettel új terápiás lehetőséget nyújthat a célszervkárosodások megakadályozásában. 


\section{Következtetés}

Habár az elmúlt évtizedben számos hatékony és modern antihipertenzív terápiás lehetőség állt rendelkezésünkre, a hipertónia okozta célszervkárosodások, különösen a HHD és a szívelégtelenség továbbra is a vezető mortalitási és morbiditási okok a hipertóniás betegek körében. Ezért egyre több vizsgálat indul, amely a célszervkárosodások kivédésére fókuszál akár a vérnyomás csökkentése nélkül is. Számos hatóanyag, mint a rezveratrol, a ROCK1/2-gátlók és a PARP-gátlók kedvező hatásúak lehetnek a remodellingre az intracelluláris jelátviteli faktorok befolyásolásával, ezért fontos részei lehetnek a jövőben a hipertóniás betegek kezelésének.

Irodalom

1. Mancia G, et al. $2013 \mathrm{ESH} / \mathrm{ESC}$ guidelines for the management of arterial hypertension: the Task Force for the Management of Arterial Hypertension of the European Society Hypertension (ESH) and of the European Society of Cardiology (ESC). Eur Heart J 2013 (34. $2159-2219$.

(1. Systolic blood pressure, diastolic blood pressure, and pulse pressure tern Med 2003; 138: 10-16. Doi 10.7326/0003-4819-138-1-200301070-00006

3. Levy D, et al. The prog

1996; 275: 1557-1562. Doi 10.1001/jama.1996.03530440037034

ne for the management of heart failure: a report of the American College of Cardiology Foundation/American

Practice Guidelines. J Am Coll Cardiol 2013; 62: 147-239. Do

1.1016j.jac.2013.05.019 patients randomized to doxazosin vs chlorthalidone: the antihypertensive and lipid-lowering treatment to prevent heart attack trial (ALLHAT). ALLHAT Collaborative Research Group. JAMA 2000; 283: 1967-1975. Doil 330: $1431-1438$.

7. Kokubo M, et al.

601-609. Doi 10.1291/hypres.28.601

8. Drazner

327-334. Doil

9. Bursi $F$, e

Systolic and diastolic heart faiture in

2209-2216. Doi 10.1001/jama.296.18.2209

mpensatory hyperfunction of the heart and cardiac insufficiency. Circ Res 1962; 10: 250-258. Doi 10.1161/01.RES.10.3.250

11. Susic D, et al. Long-term mineralocorticoid receptor blockade reduces fibrosis an improves cardiac performance and coronary hemodynamics in elderly SHR. An

12. Lip GY, et al. Hypertensive heart disea

"cardiomyopathy"? Eur Heart J 2000; 21: 1653-1665. Doi Doi [

(176: 7000-7007. Do

$\frac{10.4049 / \mathrm{jimmunol} .176 .11 .7000}{14 . \text { Schwartzkopff } \mathrm{B} \text {, et al. Mo ph }}$

\subsection{3/eurheartj/13.suppl_D.17} kidney: response to chronic angiotensin II or aldosterone administration. J Lab Clin Med

16. Ronald GV. Systemic hypertension: Mechanisms and diagnosis. Braunwald's heart disease. Textbook of cardiovascular medicine. Eds Bonow OR. Philadelphia: Elservie Saunders; 2012: p. 935-954

17. MacFadyen RJ, et al. Aldosterone blockade reduces vascular collagen turnover, imp roves heart rate variability and reduces early

patients. Cardiovasc Res 1997; 35: 30-34. D

18. Puddu P, et al. The molecul

19. Csiszar A, et al. Role of oxid

ve and nitrosative stress, longevity genes and poly(ADP-ribose) polymerase in cardiovascular dysfunction associa

20. Bendhack LM, et al. Altered signal transduction in vascular smooth muscle cells of spontaneously hypertensive rats. Hypertension 1992; 19: I|142-II148. Doi 10.1161/01.

\section{HYP.19.2_Suppl.II142}

in spontane ef hypertensive cardiopathy to heart failure in spontaneously hypertensive rats. Cardiovasc Res 2009; 83: 501-510. Doi $10.1093 / \mathrm{cvr} / \mathrm{cvp} 144$
22. Deres L, et al. PARP-inhibitor treatment prevents hypertension induced cardiac re modeling by favorable modulation of hea

isoforms. PLoS One 2014; 9: e102148. Doi 10.1371/journal.pone.0102148

23. Pacher $P$, et al. Role of poly(ADP-ribose) polymerase 1 (PARP-1) in cardiovascula

diseases: the therapeutic potential of PARP inhibitors. Cardiovasc Drug Rev 2007; 25 235-260. Doi 0.1111/j.1527-3466.2007.00018.

myocyte apoptosis. $\mathrm{J}$ Mol Cell Cardiol 2005; 38: 47-62. Doi 10.1016/j.yjmcc.2004.11.004

25. Palfi A, et al. PARP inhibition prevents postinfarction myocardial remodeling and heart failure via the protein kinase C/alycogen synthase kinase3beta pathway. J Mol Cell Carfailure via the protein kinase C/glycogen synthase kinas

26. Kataoka C, et al. Important role of Rho-kinase in the pathogenesis of cardiovascular inflammation and remodeling induced by long-term blockade of nitric oxide synthesis in rats. Hypertension 2002; 39: 245-250. Doi $0.1161 /$ hy0202.103271
27. Zeidan A, et al. Stretch-induced contractile differentiation of vascular smooth muscle: sensitivity to actin polymerization inhibitors. Am J Physiol Cell Physiol 2003; 284: C1387C1396. Doi 10.1152/ajpcell.00508.2003

for the diagnosis and treatment of acute and chronic heart failure: The Task Force for the diagnosis and treatment of acute and chronic heart failure of the European Society of Cardiology (ESC). Developed with the special contribution of the Heart Failure Association (HFA) of the ESC. Eur J Heart Fail 2016; 18 : 891-975. Doi 10.1002/ejhf.592

( United States adults 1999-2004. Hypertension 2007; 49: 69-75. Doi 10.1161/01.

\section{HYP.0000252676.46043.19} luble endothelial cell adhesion molecules (CAMs) and CAMs ligands expression in hypertensive patients on Ca-channel blocker therapy. Kidney Blood Press Res 2013; 37 : 103-15. Doi $10.1159 / 000350064$

. 32. Hartmann S, et al. The Function of Rho-Associated Kinases ROCK1 and ROCK2 in the Pathogenesis of Cardiovascular Disease. Front Pharmacol 2015; 20: 276. Do

pertension in humans. Hypertension 2001: 38: 1307-1310. Do [

20. Antioxid Redox Signal 2014; 20: 1251-1267. Do .1089/ars.2013.5524 osclerosis 2009; 205: 517-521. Doi 10.1016/j.atherosclerosis.2008.12.023

36. Bayeva M, et al. Mitochondria as a therapeutic target in heart failure. J Am Coll Cardio 2013; 61: 599-610. D 89: 481-534 (PMID: 19342613 DOI: 10.1152/physrev.00042.2007. Physiol Rev 2009; rev.00042.2007

38. Manoury B, et al. Nitric oxide synthase in postischaemic remodelling: new pathways and mechanisms. Cardiovasc Res 2012; 94: 304-315. Doi 10.1093/cvr/cvr36d

39. Clementi $E$, et al. Nitric oxide and mitochondrial biogenesis: a key to long-term regulation of cellular metabolism. Comp Biochem Physiol A Mol Integr Physiol 2005; 142: 102-110. Doi 10.1016/j.cbpb.2005.04.022

40. Miyashita K, et al. Natriuretic peptides/cGMP/cGMP-dependent protein kinase cascades promote muscle mitochondrial biogenesis and prevent obesity. Diabetes 2009; 58 . 2880-2892. D

41. Nisoli E, et al. Effects of nitric oxide on proliferation and differentiation of rat brown (P.D: 9831929) Do

42. Nisoli E, et at. Mitoch

axide. Science 2003. 290 : $890-899$

43. De Toni L, et al. Effects of type 5 -phosp

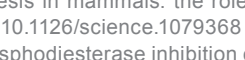

and mitochondrial biogenesis in human adipose tissue ex vivo. J Endocrinol Invest 2011 34: 738-741. Doi 10.1007/BF03346724

44. Lagouge M, et al. Resveratrol improves mitochondrial function and protects against metabolic disease by activating SIRT1 and PGC-1alpha. Cell 2006; 127: 1109-1122. Doi 10.1016/j.cell.2006.11.013 tions of resveratrol promotes NO production in vascular endothelial cells. Br J Nutr 2012 107: 774-780. Doi $10.1017 /$ S0007114511003588

46. Zang M, et al. Polyphenols stimulate AMP-activated protein kinase, lower lipids, and inhibit accelerated atherosclerosis in diabetic LDL receptor-deficient mice. Diabetes 2006; 55: 2180-2191. Doi $0.2337 / \mathrm{db} 05-1188$

(hevelopment of pathological cardiac hypertrophy and contractile dysfunction in the SHR without lowering blood pressure. Am J Hypertens 2010; 23: 192-196. Doi 10.1038/ajh.2009.228

48. Biala A, et al. Resveratrol induces mitochondrial biogenesis and ameliorates Ang II-induced cardiac remodeling in transgenic rats harboring human renin and angiotensinogen genes. Blood Press 2010; 19: 196-205. Doi 10.3109/08037051.2010.481808

49. Rimbaud $S$, et al Resveratroli rat model of hypertension leading to heart failure. PLoS One 2011; 6: e26391. Doi 10.1371/ ournal.pone.002639

Combination effects of enalapril and losartan on lipid peroxida$10.1159 / 000228714$

51. Goyal BR, etal. Beneficial role of spironolactone, telmisartan and their combination on isoproterenol-induced cardiac hypertrophy. Acta Cardiol 2012; 67: 203-211. Doi 10.1080/ AC.67.2.2154211 hopeless illusion? Pharmacol Res 2014; 90C: 88-115. D

53. Thandapilly SJ, et al. Reduced hemodynamic load aids Io.1016/. phr

ing cardiovascular defects in hypertensive rats. Hypertens Res 2013; 36: 866-872. Do

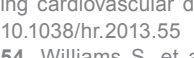

54. Williams S, et al. Ranolazine improves diastolic function in spontaneously hypertensive rats. Am J Physiol Heart Circ Physiol 2014; 306: H867-H881. Doi 10.1152/ajp-

tects of recombinant adenovirus hepatocyte growth factor gene on myocardial remodeling in spontaneously hypertensive rats. J Cardiovasc Pharmacol Ther 2013; 18: 476-480. Doi 10.1177/1074248413490832

56. Magyar K, et al. A quinazolinederivative compound with PARP inhibitory effect sup presses hypertension-induced vascular alterations in spontaneously hypertensive rats. Biochim Biophys Acta 2014; 1842: 935-944. Doi 10.1016/j.bbadis.2014.03.008 57. Bartha $E$, et al. Regulation of kinase cascade activation and heat shock protein expression by poly(ADP-ribose) polymerase inhibition in doxorubicin-induced heart failure. Cardiovasc Pharmacol 2011; 58: 380-391.Doi 